\title{
Redistribution, Growth, and Inclusion: The Development of the Urban Housing System in China, 1949-2015
}

\author{
Wenjing Deng*, Joris Hoekstra, Marja Elsinga \\ OTB-Research for the Built Environment, Delft University of Technology, Delft, The Netherlands \\ Email: *w.deng@tudelft.nl
}

How to cite this paper: Deng, W. J., Hoekstra, J., \& Elsinga, M. (2017). Redistribution, Growth, and Inclusion: The Development of the Urban Housing System in China, 1949-2015. Current Urban Studies, 5, 423-443.

https://doi.org/10.4236/cus.2017.54024

Received: September 13, 2017

Accepted: December 4, 2017

Published: December 7, 2017

Copyright ( 92017 by authors and Scientific Research Publishing Inc. This work is licensed under the Creative Commons Attribution International License (CC BY 4.0).

http://creativecommons.org/licenses/by/4.0/

\begin{abstract}
This paper explains the development of the urban housing system in China from 1949 to 2011 with an emphasis on the factors driving housing inequality in each policy period. We argue that the logic underpinning the housing policy had shifted from socialist redistribution to the stimulation of growth in the process of market economy reform and has been shifting toward social inclusionary growth since the 2010s. Over the course of time, two institutional factors (work units and household registration/hukou) have played a key role in determining individual households' housing opportunities. The role of the work units has gradually waned since the 2000s, but the hukou system continues to be important. In the last part of the paper, we set forth the latest changes in Chinese housing policy. Since 2011, the central government has been striving toward a more comprehensive system of housing provision with the aim of making the housing market more inclusive (though not necessarily more equal). Finally, we express concern about an emerging though embedded source of housing inequality: the unequal distribution of family wealth.
\end{abstract}

\section{Keywords}

Housing Policy, China, Market Transition, Hukou Reform, Social Inclusion

\section{Introduction}

The People's Republic of China was established in 1949 and has since undergone enormous institutional changes. From the radical communism and socialism of the Mao Zedong era to the more realistic Socialism with Chinese Characteristics (Qiu, 2000), the pronouncements and policies have been adjusted to address the 
mismatch between political ideals and economic realities, between policy goals and social responses. When the plan economy ran into difficulty, Deng Xiaoping, the communist leader in the late 1970s and 80s, initiated reforms to develop a market economy with Chinese Characteristics. In that vision, economic growth would get a boost from market forces and non-public organizations without undermining the legitimacy of socialist leadership.

Throughout this transition, China applied a gradual and incremental dual-track approach. Its dualism reflects the parallel existence of a new (i.e., market) and the old (i.e., plan) system. If the new track produced stronger growth, the old one would be phased out (Fan, 1994; Lau et al., 2000). China's housing reform took a dual-track approach too. The new track of commodity housing, in the form of home ownership, eventually replaced the old track of welfare housing (Figure 1).

The aim of this paper is to describe the relation between the urban housing system and social structure against the backdrop of transition in China. Our investigation is based on housing policy documents, data from secondary sources, and a review of previous research findings. The research question is:

How has the provision of urban housing in China changed in the transition period in line with two institutional shifts (with regard to the role of the work units and the hukou registration), and how has this influenced housing opportunity?

In the following sections, we first introduce two institutional elements of the

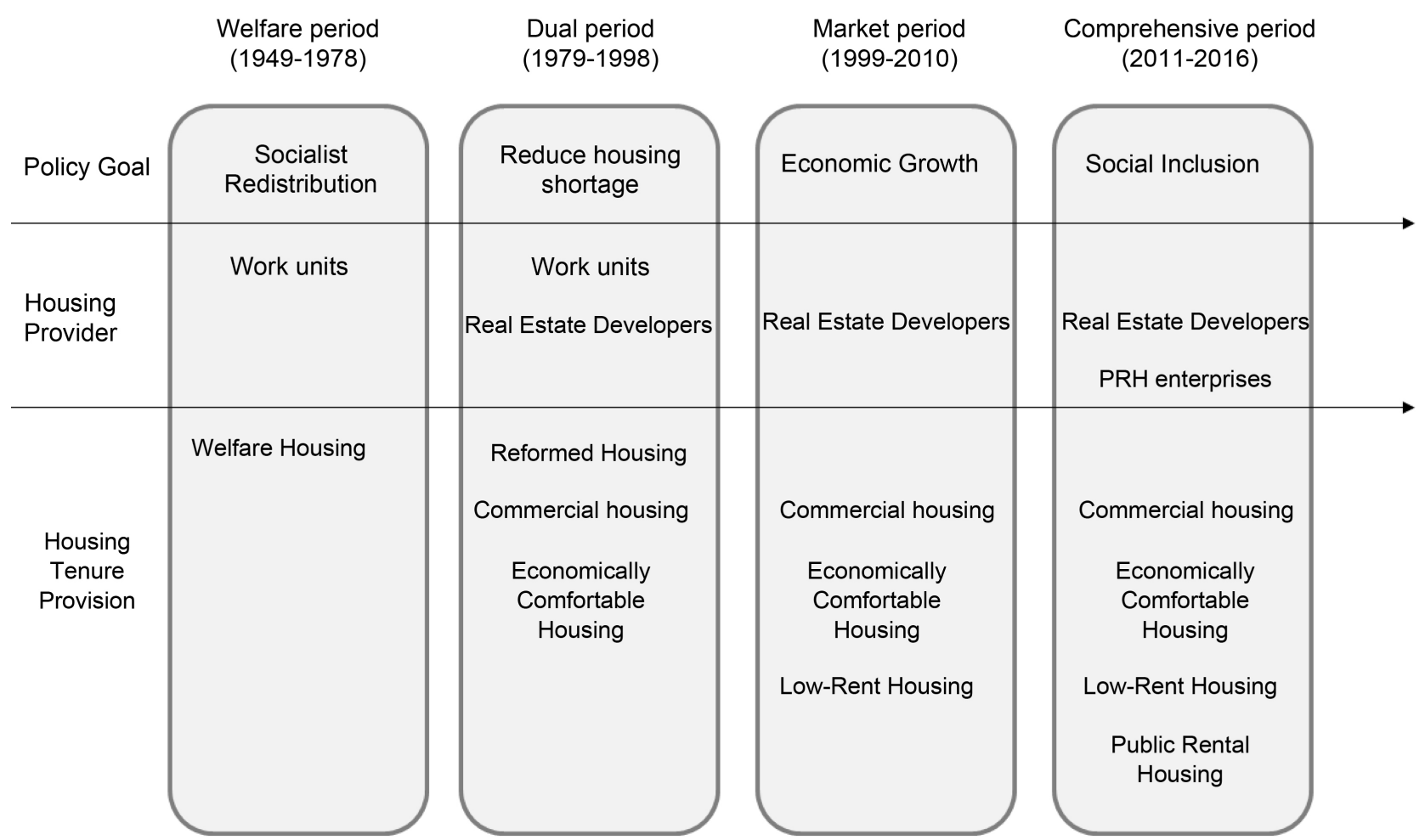

Figure 1. Four periods of housing development in China. 
Chinese housing system (the work unit and hukou registration) and explain their historical development. Then we outline the changes in housing policy and their impact on inequality in three periods prior to 2011. Over the course of time, the logic of housing policy has shifted from egalitarian redistribution to the stimulation of economic growth. In the last part, we analyze recent developments in housing policy. We tie these to the changes in the social-economic context that have precipitated them. Sketching the contours of a fourth period, we identify changes that seem to be making Chinese housing policy more inclusive. Finally, we draw attention to an emergent though embedded source of housing inequality: the unequal distribution of family wealth.

\subsection{Redistributive Mechanisms and the Role of the Work Units}

The concept of non-market trade was introduced by the Polish Economist Polanyi to describe economic activities in Socialist Poland, where the exchange of goods was not subject to the free will of traders but to the orders of the authorities. Inspired by Polanyi, the Hungarian political economist Szelenyi coined the term "redistributive economy" (Szelenyi, 1978), applying non-market socialist features to the activities of organizations devoted to the distribution of welfare goods. In a market economy, Szelenyi argued, ability in the labor market would determine the households' access to welfare. Accordingly, inequalities in market economies are caused by differentials in market ability and mitigated by government intervention. In a redistributive economy, in contrast, access is determined by their position in the socialist redistributive system, or by their affinity to redistributive power. Thus, Szelenyi argues, in socialist societies there are "redistributive mechanisms" in which the administrative allocation of scarce goods and services favors "redistributors", e.g., socialist elites, over "immediate producers", e.g., agrarian workers. Such mechanisms constitute the main source of inequality in redistributive economies. In Hungary, the redistributive mechanism is manifest in housing allocation but also in the price of consumer goods and cash and non-cash allowances.

This argument is applicable to socialist China. The Chinese redistributive mechanism was built on a centralized danwei hierarchy that combined productive and administrative functions (see Womack, 1991; Francis, 1996; Perry, 1997). In this system, the planning department of the central government determined industries' inputs and their allocation of output. The department then distributed these resources and assigned production quota across various levels of danwei (work units). Since these units occupied different positions in the hierarchical system, their ability to acquire resources and provide welfare goods differed widely. Usually, the larger work units, the units higher in the administrative ranking, and crucially those in industrial sectors such as steel and machinery tended to have stronger "redistributive power". And employees of powerful units enjoyed better public services than others. As Perry (1997: p. 44) noted, the 
system "privileged a minority of the urban industrial work force at the expense of the majority."

In the socialist period, the work units provided housing, education, healthcare, and pensions; after retirement, one's pension was paid by the former work unit. Under the corporate reforms of the 1990s, which fell under the transition to a market economy, the units were stripped of their function of providing social services. That function was transferred to local government (Wu, 2002). The initial goal of the corporate governance reform was to relieve state-owned enterprises of their welfare burden so that these companies could compete in the market. In 1995 and 2002, the central government issued several decrees encouraging state-owned enterprises to get rid of their pension duty and divest themselves of affiliated organizations such as schools and hospitals (State Commission of Economy and Trade, 1995; State Commission of Economy and Trade et al., 2002). Schools were transferred to local educational bureaus; hospitals and other services were brought under dependent for-profit corporations. Pension duties were shifted to newly instated pension bureaus and managed locally by a "street office" (jiedao banchichu). Housing had gone through a stage of retrenchment from its role in the provision of socialist welfare goods. That role was taken over by a system of market allocation in which real estate developers replaced work units as the main housing providers (Zhang, 2002).

\subsection{Market Transition and Household Registration (Hukou) Reform}

Given China's long agricultural tradition, the government had never supported mobility. Throughout history, the rulers had always seen free movement as a seedbed of social, political, and economic upheaval. The policy of registering residents and forbidding migration dates back to 200 A.D. Then, in 1958, China launched the hukou system to connect residential registration with goods allocation (Perry, 1997; Wu \& Treiman, 2004; Huang et al., 2013). By preventing rural-urban migration, the government could ensure that the limited amount of goods being produced would sustain the population of the cities. In that sense, the hukou system formed part of a strategy to support the development of modern industry by giving less priority to agriculture and promoting construction in urban areas.

A local urban hukou was a tool of redistribution and as such was required for access to commodities including food, clothing, housing, education, and all kinds of public services. After the market reform, the Pearl River Delta was the locus of an economic boom, and the government began to tolerate rural-urban migration to satisfy the demand for labor there (State Council, 1984). But without a local hukou and lacking skills, these migrant workers usually had low-paid temporary jobs. Governments and employers were reluctant to provide them with public services and welfare goods. Understandably, in the absence of secure 
employment and without access to public services, migrant workers maintained a limited lifestyle in the cities and brought back as much savings as they could to their rural home (Cheng \& Selden, 1994; Chan \& Zhang, 1999). They were called the "floating population" (liudong renkou).

Although these migrants were encouraged to work in the cities, their access to housing was restricted. For the most part, they found accommodation at their workplace, in a slum, or in illegal construction on the outskirts (Wu, 2002; Wu, 2004; Jiang, 2006; Liu et al., 2013). More housing options appeared in the 1990s, along with the promotion of commodity housing. To that end, the "blueprint hukou" was invented and issued to migrant homebuyers; with it, they could be treated more like local citizens, though not as their equals (State Council, 1998a; $\mathrm{Wu}, 2001$; Jiang, 2006). Buying a house in the city became the best means of changing one's hukou status and improving one's position (Huang, 2015).

Not only had the migrants' contribution to prosperity in the cities been long ignored, but they were stigmatized as the cause of urban problems such as poor public hygiene and crime. Lately this stereotype has been fading and their presence is being addressed in policies (Wang, 2004; Bian, 2013). Scholars have emphasized their importance to prosperity, voicing the expectation that by improving their situation the migrants will become stronger, more devoted citizens. Their increased purchasing power is said to eventually benefit the Chinese economy. This especially applies to recent times in which the Chinese economy went into a so-called new normal stage (National Academy Administration, 2014). In this stage, the conventional drivers of economic growth such as manufacturing and exportation are stagnating and China's economy is becoming increasingly dependent on domestic demand, including the demand exerted by migrant workers.

In response, the central government decided to "fully open" the possibility to transfer one's hukou to small townships and cities but to be more cautious about allowing open access in big cities (State Council, 2014a). Ultimately, the government would seek to unify rural and urban hukou registration under one "residential registration" and then build a database on it to support other welfare reforms. Thereby, public education, employment, healthcare, pensions, and housing, among other benefits, would gradually cover all regular residents. This reform was expected to help about a hundred million people, including rural immigrants, settle in townships and cities. By October 2015, 24 of 31 provinces had published their intentions and plans to carry out this reform (People.cn, 2015).

The next section describes the housing policy of China from 1949 to 2011 in three time periods. For each period, the tenure structure and the changes in housing policy are examined, giving particular attention to the relevance of work units and hukou in housing allocation and the impact of policies on housing inequality. 


\section{From Redistribution to Growth}

\subsection{9-1978: The Establishment of a Redistributive System}

\subsubsection{Transition in Structure of Housing Tenure}

The predominant tenure in this period was welfare housing, which comprised rental dwellings provided by the municipality or work units for a token rent. The public rental housing sector increased from about $48 \%$ to $72 \%$ between 1949 and 1994 (Huang, 2004; see Table 1) through nationalization of the stock and new construction (Wang, 1995; Zhang, 1997). In the same period, the proportion of private ownership decreased from around $35 \%$ to $25 \%$, whereas the share of private renting shrank from $17 \%$ to $3 \%$ (Huang, 2004).

Under this system, housing allocation was aligned with the political commitment to socialism and people's "contribution" to the planning economy. That integrated system ensured the maximum exposure of people to the ideal of collective living (jiti shenghuo) and helped educate citizens to be socialists. By the end of the 1950s, most big cities had managed to keep the rent-to-income ratio under 10\% (Zhang, 1997). And to keep housing affordable, urban planners designed multi-story dormitories in which several families would have their own bedroom but share a kitchen and bathroom.

Table 1. Tenure distribution ${ }^{1}$ from 1949 to 2011, percentage.

\begin{tabular}{ccccccc}
\hline & & 1949 & $1978^{2}$ & $1996^{3}$ & $2000^{4}$ & $2011^{5}$ \\
\hline \multirow{3}{*}{ Rent } & Public & 48 & 72 & & 28 & 3.4 \\
& Private & 17 & 3 & 45.7 & & 13.7 \\
& Heritage or self-build & 35 & 25 & & & 23.1 \\
\multirow{3}{*}{ Own } & Reformed housing & - & - & & 72 & 15.8 \\
& Subsidized housing & - & - & 46.6 & & 7.0 \\
& Commodity housing & - & - & & & 29.6 \\
& Free & - & - & 4.1 & - & 4.5 \\
& Other & - & - & 3.5 & - & 2.9 \\
\hline
\end{tabular}

${ }^{1}$ We have tried to provide a historical overview of the tenure distribution. However, this is very hard due to lack of consistent data. We cite several sources in order to be as comprehensive as possible. Readers also need to bear in mind that the tenure distribution varies across cities. The general principle is that the homeownership rate is higher in small cities (Huang \& Clark, 2002: p. 16) and in cities where the public sector is less predominant ( $\mathrm{Li}, 2000)$.

${ }^{2}$ The data from 1949 to 1978 comes from "The State and Life Chances in Urban China" conducted in 1994. The sampling includes 2478 respondents from 20 cities from 6 provinces and capital cities. Households who started their housing career before 1949, and those who bought their first home before taking their first job were excluded from the database (cited from Huang, 2004).

${ }^{3}$ The data for 1996 comes from "Life Histories and Social Change in Contemporary China" conducted in 1996. It is a national survey using a multistage probability sampling (cited from Huang \& Clark, 2002).

${ }^{4}$ The data for 2000 comes from the Fifth Census, which covers 10\% of the residents (cited from Bian \& Liu 2005).

${ }^{5}$ The data for 2011 comes from the Chinese Household Finance Survey 2011 and calculations by the authors. The data is available in http://www.chfsdata.org/. 


\subsubsection{Policy Goals and Instruments}

Work units and local government allocated dwellings by means of waiting lists, using a ranking system in which points were assigned to indicate one's contribution to society. When a housing complex had been completed (or planned), the employee at the top of the list would have first choice of a dwelling, then the next worker and so on. The parameters for calculating one's contribution to society included how many years the employee had served in a work unit, his or her administrative rank, CPC membership, political status, household size, and current living conditions (Wang, 1995; Zhang, 1997; Wang \& Murie, 2000). Consider an example from 1955. In Xi'an, the capital of Shaanxi province, housing allocation by the provincial authority was based on the administrative rank of the household head. If that rank was equivalent to a provincial governor, a family could be allocated a maximum of $60-95 \mathrm{~m}^{2}$; the families of those whose rank equaled that of a department chief could be allocated $46-68 \mathrm{~m}^{2}$ at most; and ordinary workers were allocated a maximum of $5 \mathrm{~m}^{2}$ (Wang, 1995: p. 66).

\subsubsection{Impact on Housing Inequality}

Two dimensions of inequity can be distinguished in this traditional welfare system: vertical and horizontal (Logan et al., 1999; Zhao \& Bourassa, 2003). Vertical inequity refers to the differences within the work units and between different administrative ranks, as in the example of Xi'an above. Horizontal inequity refers to the difference among work units in terms of economic power (industry, size, and profitability) and administrative rank (at the national, provincial, municipal, or collective level) (Zhao \& Bourassa, 2003). Usually, state-owned work units were more prestigious than collectively owned or private ones. Actually, state-owned enterprises were given the highest priority in the provision of land, capital, and housing (Zhang, 1997: p. 449).

\subsection{9-1998: Gradual Reform and Dual Provision}

\subsubsection{Transition in Structure of Housing Tenure}

At a national administrative conference in 1978, housing provision was given priority, prompting the decision to initiate a housing reform. The aim was to solve the housing shortage and reduce government expenses at the same time. Work units and individuals were encouraged to invest more in urban housing. Moreover, in-kind housing provision was replaced by a policy of monetary distribution (State Council, 1978).

From the start of the housing reform in 1978 till its termination in 1998, housing was mainly provided under two models: reformed housing (fanggai fang, or privatized housing) and commodity housing (shang pin fang). Reformed housing consisted of dwellings that had been developed by work units or governments and sold to households, usually at a subsidized price. Commodity housing consisted of dwellings built on leased urban construction land by real estate developers and sold on the open market at market prices. During this period, the share of the home ownership sector increased from a quarter to almost 
half of the stock (Table 1).

\subsubsection{Policy Goals and Instruments}

Both reformed and commodity housing started out as pilot projects. The first one was carried out in the late 1970s and second in the early 1980s; both projects then became a nationwide effort in 1988. In the public sector, stock was sold to sitting tenants initially at the market price and later at a subsidized price. Work units were also allowed to construct housing-or buy new dwellings from private developers if they had no land or capacity to do it themselves-to sell to workers with subsidy.

In 1988, a constitutional amendment made a privatized economy lawful, thereby allowing land-use transfer. From then on, for-profit development of commodity housing on urban land was both permitted and encouraged. A series of policies promoted the supply and consumption of commodity housing. On the supply side, the practice of for-profit land-leasing quickly became an important source of income for local governments and was the target of preferential policies. Moreover, the option of pre-sale was introduced, allowing developers to sell dwellings before completion. This practice enabled them to use the buyers' money to build housing, thereby extending the scope of housing provision substantially (State Council, 1994). A Housing Provident Fund (HPF) was launched, consisting of compulsory contributions by both work units and workers. Funds were initially allocated to housing construction and later to housing consumption.

On the demand side, purchasing power was strengthened by directing the HPF to homebuyers and opening up the mortgage market. Participants in the HPF (mainly workers in the formal public sector) could withdraw money from their personal accounts or take out loans at a low interest rate when purchasing homes. Four State-owned commercial banks were allowed to originate mortgages for all kinds of lenders, and later on emerging private commercial banks were also included in this business. Limitations on loan amounts and maximum loan periods were relaxed, and down payments were no longer required (State Council, 1998b).

The 1994 housing reform introduced another type of tenure, called Economic Comfortable Housing (ECH, jingji shiyong fang, which some scholars translate as Economic Affordable Housing). ECH was expected to cover at least $20 \%$ of the housing provision (State Council, 1994). But since it was not profitable enough, neither local governments nor developers felt any incentive to take action in this tenure, and its provision dropped below $10 \%$ in the next period (Barth et al., 2012).

\subsubsection{Impact on Housing Inequality}

Overall housing quality improved substantially for urban households in terms of floor space and facilities. From 1979 to 1998, the average living area per capita in urban China increased from $3.6 \mathrm{~m}^{2}$ to $13.6 \mathrm{~m}^{2}$ (NSB, various years). At the same 
time, the inequality of housing distribution increased, especially between workers in different sectors and work units. During the welfare period, the housing differences among various work units had been partly mitigated by taking extra resources from big and rich work units to support small and poor ones. When the reform was terminated, such redistributive measures stopped too. Enjoying a monopolistic position in the market, the richer work units had a stronger capacity to provide adequate housing at a lower cost (Zhao \& Bourassa, 2003).

The position of the employees differed in two respects. First of all, only workers in powerful and profit-making work units had access to subsidized reformed housing (Huang \& Clark, 2002; Sato, 2006). The policies to strengthen affordability only benefited urban workers with a local hukou, especially those in powerful work units (Zhou \& Logan, 1996). Secondly, the cost structure of reformed housing and commodity housing is very different. The average price of commodity housing on the open market is about five times that of reformed housing; rents in the public sector are on average one-fifth of those in the private rental market (Logan et al., 2010).

During this period, much of the work unit stock had not yet been privatized. Since the inhabitants of this stock occupied stable rental housing and expected reform in the future, they had no incentive to buy. Therefore, households in better-off work units actually had a rather low rate of home ownership (Li, 2000; Ho \& Kwong, 2002; He et al., 2012; Huang \& Clark, 2002; Mao, 2014). But by the time the period of housing reform was over and their housing was finally privatized, households in better-off work units would have gained more capital (calculated by the current value of their dwelling minus the purchase costs) than households in other work units (Li, 2009).

The dual-track provision of urban housing has resulted in a dual housing market. Employees in powerful work units benefited from the strong subsidy on reformed housing provision, while the rest of the population had been forced into costly market housing. With this dual system, a different degree of affinity to redistributive power resulted in a substantial difference in accessibility and cost of assets. Persons who had been privileged in the original socialist system maintained their privileges through the reformed system of housing allocation.

\subsection{9-2010: The Market-Dominant Period and Market Regulation}

\subsubsection{Transition in Structure of Housing Tenure}

From 1998 on, the central government had forbidden work units to provide reformed housing to their employees (State Council, 1998b); nonetheless, they continued to do so, albeit at a smaller scale in the early 2000s. As China entered a market-dominant period of housing provision, the development of commodity housing was seen as a pillar of economic growth (State Council, 2003). The proportion of investment flowing into commodity housing increased from $50 \%$ in the late 1990s to about $85 \%$ after 2005 . The proportion of affordable housing, 
mainly Economic Comfortable Housing (ECH), dropped from 17\% in 1999 to 2\% in 2011 (Barth et al., 2012).

In terms of the tenure structure, the proportion of owner occupation rose to 75.5 in 2011 (Table 1). By then, $29.7 \%$ of the population had bought their home in commodity housing, $15.9 \%$ in reformed housing, and $7.1 \%$ in subsidized housing such as ECH. The rental sector accounts for $17.2 \%$ of the stock: of this share, $3.4 \%$ is rented in the public sector and $13.8 \%$ from private owners.

\subsubsection{Policy Goals and Instruments}

The authorities faced a difficult choice in this period: whether to sustain economic growth and keep the real estate industry prosperous, or to curb house price inflation and improve affordability. After 2006, in reaction to criticism that untargeted supply-side regulation harmed ordinary households by putting pressure on affordability, the central government developed targeted and sophisticated measures. It tried to strike a balance between economic growth and affordability, as reflected in the three-pronged approach to housing policy in this period.

The first aim was to regulate the housing provision process. Issues related to the construction boom-such as ecological damage, illegal land use, and relocation conflicts-drew attention nationwide. In the early 21 st century, the central government began to regulate the land and real estate markets. Procedures were formalized and standardized to make them more transparent and ultimately to prevent illegal transactions and corruption.

The second one was to adjust the provision structure so that ordinary commodity housing would not be outpaced by luxury commodity housing. Policies were drafted to secure land provision for ordinary commodity housing and subsidized affordable housing. The land for ordinary commodity housing (with less than $90 \mathrm{~m}^{2}$ of floor space) was supposed to take up at least $70 \%$ of the total provision of residential land (MHURD et al., 2006; State Council, 2011).

The third one comprises purchase limitations and stricter mortgage regulations. From 2006 on, a 30\% down payment was required for mortgage loans. Since then, the requirements for mortgage loans have been tightened further and interest rates keep rising. There were also restrictions related to the number of other properties a prospective buyer could already own. These measures reflect a more precisely targeted attempt to deleverage speculators. This regulatory effort went as far as adopting a purchase and mortgage loan prohibition in 2010, whereby prospective buyers who do not possess a local hukou, pay no tax, or do not participate in a social security fund are forbidden to buy (MHURD et al., 2006; State Council, 2011). Restrictions such as these do weed out the speculators. But at the same time they exclude many people who are in need of housing and who are even at a disadvantage in the local housing market; that is, the policy is detrimental to immigrant workers.

These regulations were not applied consistently, however. The central gov- 
ernment tends to restrict housing transactions and tighten the provision of land and finance when a bubble is believed to exist. Such restrictions are then relaxed when signs of economic stagnation appear, as they did in 1997 and 2008 (Barth et al., 2012).

\subsubsection{Impact on Housing Inequality}

While the average living area per capita increased from $13.6 \mathrm{~m}^{2}$ to $32.7 \mathrm{~m}^{2}$ between 1999 and 2011 (NSB, 2013), housing inequality increased too. This was caused by the dual provision of reformed and commodity housing as well as by house price inflation (Huang \& Li, 2014; Fang, 2014; Yi \& Huang, 2014). Reformed housing provision offered privileged households a shortcut to home ownership at relatively low cost (Li, 2009; He et al., 2012). Their advantage was further enhanced by the inflation of house prices.

Meanwhile, a new trend had emerged. During the welfare and dual periods, the main criteria for dwelling allocation had been related to variables indicating the 'affinity' to redistributive power such as membership of the CCP, work unit category, and cadre rank (Zhang, 1997). After the housing reform, despite the persistence of redistributive processes (Chen, 2011; Chen, 2012; Li \& Li, 2006; Deng et al., 2016), market-oriented factors such as education, occupation, and total household income began to have an impact (Chen, 2011; Logan et al., 2009; Luo, 2013; Huang et al., 2013; Huang \& Jiang, 2009; Pan, 2003; Yi \& Huang, 2014). Research shows that different institutional elements followed different paths in the reform (Huang \& Jiang, 2009; Chen, 2015).

\subsection{Onward: The Advent of Social Inclusion?}

\subsubsection{Social Inclusion and the "New Normal"}

Back at the beginning of the reform in the late 1970s, the chief reformer, President Deng Xiao Ping, stated that the goal of the reform is to let one group of people get rich first, then they will help the rest and reach prosperity together. Well into the 21st century, there is no doubt that one group of Chinese people has become rich already. The question remains, how to reach prosperity together. Under the pressure of economic growth, appeals for social development can hardly compete with economic goals. But in the mid-2000s, the communist party proclaimed its intention to establish a "harmonious society". One of its goals was to "equalize basic public service", including education, social security, housing, and culture. In 2012 the state council drew up a plan for achieving that goal, so that "all citizens can equally access basic public service in general equal terms. The core is equal opportunity rather than simply averaging and undifferentiation" (State Council, 2012). After many years of double-digit growth since the start of the economic reform, the growth in Gross Domestic Product dropped below 8.0\% after 2012 and below 7.0\% in 2015 (World Bank, 2016). President Xi Jinping, who took office in 2012, called the situation the "new normal" and proposed to adjust economic and social policies accordingly. Under the new normal, China will not continue its rapid growth but will face adjust- 
ments in the industrial structure. The policy emphases will shift to services, innovation, reduced inequality, and environmental sustainability (National Academy Administration, 2014). Policy under the new normal seeks to facilitate the growth of unconventional industries and consumption by middle- and lower-income households and rural migrants to replace conventional "growth drivers", which are declining.

\subsubsection{Housing Challenges under the New Normal}

Under the new normal, the housing market is confronted with an increasing amount of unsold stock and stagnating prices. Unlike 1998 and 2008, when the economic downturn in China was mainly the result of the global economic crisis, the housing market stagnation in 2014 was mainly due to domestic conditions: weak demand, affordability problems, difficulty profiting from conventional industries like manufacturing and exporting, and demographic changes. From 2011 on, housing consumption by first-time buyers ceased to dominate the market. New entrants were outpaced by households who already owned housing (to trade up or hold for investment). Increased housing need (among a new cohort of grown-up immigrant workers, and among residents displaced by demolition) accounts for only one-third of current demand, and most of the new home-seekers have difficulty affording to buy (Gan et al., 2013).

\subsubsection{A Comprehensive Housing Approach}

Housing provision in this period shifted toward a comprehensive approach in which both home ownership and public rental housing were made available to different groups of consumers (Deng et al., 2011). This shift went hand in hand with two institutional changes: hukou reform and real property registration. Together these reforms would make taxation of speculative investment in housing properties technically possible. These two fundamental changes were envisaged as empowering rural immigrants to compete on more equal footing with their local peers in the urban market.

\subsubsection{Housing Subsidy: From Owner-Occupation to Renting}

The focus of large-scale housing schemes turned away from subsidized home ownership, represented by Economic Comfortable Housing, toward rental housing. There were two reasons to expand the public rental sector. On the one hand, a home of one's own had become unaffordable, even at a discount, to low-income households. On the other hand, the potential for profiting from home ownership attracted illegal acquisition practices and corruption (China.cn, 2011).

Subsidized rental schemes fall under two headings: Low-Rent Housing (LRH, lian zhu fang, which some scholars translate as Cheap-Rent Housing); and Public Rental Housing (PRH, gong gong zhu ling fang). The Low-Rent Housing scheme, which was started nationwide in 2003, targeted the lowest-income households with a local urban hukou. Public Rental Housing, which was started 
in 2010, puts lower requirements on tenant eligibility and therefore receives less subsidy (Figure 2). From 2014, local governments were required to harmonize the LRH and PRH schemes, which had different levels of rent subsidy (based on income of the households and affordability criteria). And they were also encouraged to set up transparent procedures for allocation, such as a queue or lottery.

As envisioned by the central government, PRH schemes should also cover the housing needs of migrant workers (General Office of State Council, 2013). Some municipalities did indeed abolish the requirement of a local hukou (Wang \& Li, 2011). Nonetheless, to meet the eligibility criteria, migrants still need proof of, among other things, stable employment, a certain number of years of residence, and/or a certain number of years of social security payments.

\subsubsection{Housing Subsidy: From Bricks to People}

In an inquiry held in Congress in 2011, the Minister of Housing and Construction laid out a plan and timeline for shifting housing subsidy from bricks to people by the end of 2015 (China.cn, 2011). The current approach of constructing affordable housing with government subsidy would be phased out. All sources of vacancy, ranging from unsold commodity housing to sell but unoccupied privately owned housing, should be tackled. For instance, empty dwellings should be included in the pool and then made affordable to tenants by means of rent subsidy. This approach started as a pilot in 2016 in the provinces of Neimenggu and Fujian (MHURD, 2016). It has also been decided to revise the HPF regulation. The new version would make the contribution of private employers more rigid and allow account-holders to withdraw funds to pay their rent (MHURD, 2015). Previously, poor participation among private employers led to unequal benefits for employees in the public versus the private sector. And a consequence of the policy to allow only homebuyers to make withdrawals from an HPF account was that renters, who usually have more difficulty affording housing, can contribute to the HPF but cannot benefit from it.

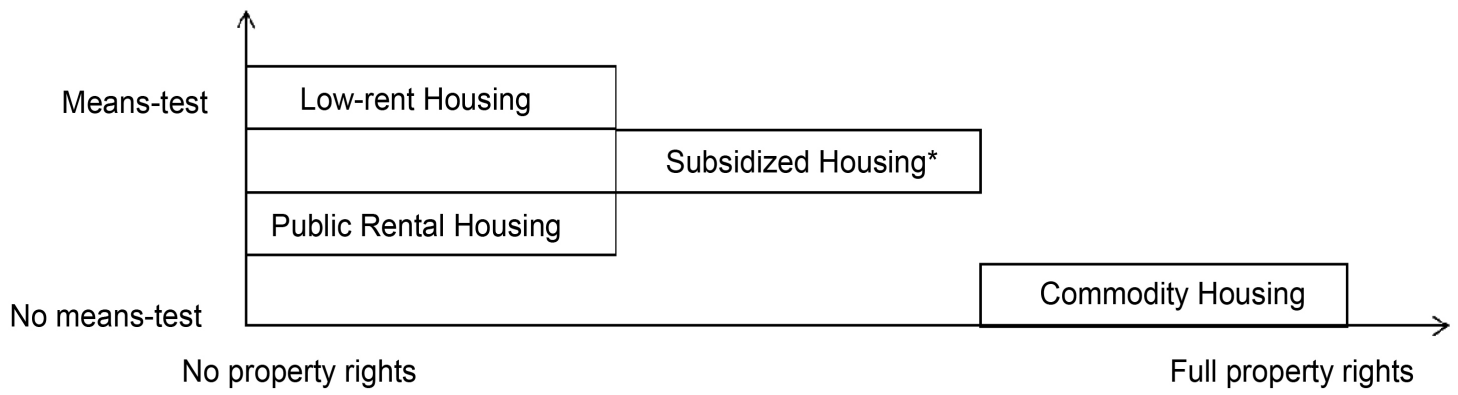

Figure 2. Characteristics of current housing tenures in urban China. Note: This Figure describes the general condition of housing tenure in China; a slight difference, sometimes significant, exists among cities. ${ }^{*}$ Subsidized Housing has conditional property rights such as not allowing resale within five years and imposing a supplementary land fee upon resale. The category includes reformed housing, $\mathrm{ECH}$, compensation housing for expropriation, etc., depending on local legislation. 


\subsubsection{From Purchase Prohibition to Tax Differentiation}

The policy to prohibit purchase and impose a higher mortgage interest rate on buyers who do not possess a local hukou, envisioned as a means to regulate speculation in the 2010s, was harshly criticized for "distorting" the market. The minister explained that this policy was enacted as a temporary expedient measure and would be abolished as soon as the real estate registration system was in place. Establishing such a registration system was difficult "beyond expectations". The main challenges were to include information on all family members and figures for other relevant administrative measures such as taxation (China.cn, 2011).

Once the registration system is in place, it will make taxation on extra housing or vacant dwellings technically possible. In turn, the new system would discourage speculation and thereby promote provision to legitimate homebuyers. China started to charge real estate tax on some luxury and non-primary dwellings in 2011. That was the first time since the establishment of China that ownership of residential property had been taxed. Like other housing policies, the real estate tax reform started with pilot schemes, this one in Shanghai and Chongqing. Shanghai charged a fixed rate on a second home for owners with a local hukou and on any home for owners without one. Chongqing imposed progressive tax rates on owners of newly purchased luxurious dwellings, as well as on owners of a second home who did not have local hukou papers.

The central government affirmed that China will "accelerate real estate tax legislation" with the goals of "improving the local tax system" and "increasing the proportion of direct tax" (Third Plenary Session of the Eleventh Central Committee of the CPC, 2013). The government hopes to achieve a sustainable revenue by replacing the one-off land leasing fees with real estate taxes, which will be renewable every year.

\subsubsection{Real Estate Registration}

The Provisional Regulation of Real Estate Registration (State Council, 2014b) confirms rural (and other) citizens' property rights on farmland, construction land, forests and grassland, and constructions and structures. Such a formal confirmation will help rural citizens turn their rural property into liquid assets and participate in economic activities according to market principles. If these reforms in the taxation and registration systems are successfully implemented, rural and urban citizens will be able to compete more fully and equally in the market, on both the production and consumption sides. Such an information system would also provide the technical basis for nationwide taxation on real property.

\subsubsection{Inclusive but Not Equal?}

In the dual and market periods (1978-2010), the housing disadvantages of rural immigrants were mainly due to institutional barriers, which obstructed their access to formal housing and better jobs (Wu, 2002; Wu, 2004; Jiang, 2006). For people having no access to subsidized housing but faced with the higher price of 
commodity housing, a local hukou status then became an effective predictor of better housing outcomes (Chen, 2012; Huang \& Jiang, 2009), especially among young people (Deng et al., 2016).

After hukou reform, having a local hukou turned out to be irrelevant to people seeking to attain home ownership in the less-developed municipalities. It is still significant in more-developed municipalities, though, since the housing purchase entitlements are higher there (Huang et al., 2013). Even holding a $h u-$ kou registration in close proximity (for example, in the same province but a different municipality) gives them a better chance of entering the home ownership sector (Huang et al., 2013; Deng et al., 2016). An alternative explanation of the differences in access for first-time buyers lies in the degree to which locals and immigrants can count on financial support from family (Cui et al., 2016).

This policy thrust has ushered in a new trend toward housing opportunity. After this wave of reform, housing allocation might be less dependent on institutional factors. Accordingly, rural migrants and local residents might have equal access to the urban housing market, as envisioned in the basic public service plan. But the difference in wealth between the new residents and the original families (Wang, 2013) might still block a group of citizens from equal outcomes in living conditions, even if they have similar incomes from labor market participation. And a large part of such a difference in household wealth comes from the different amount of housing benefit that families receive from the reform of housing privatization rules (Li, 2009; Gan et al., 2013), since a big chunk of family wealth goes toward housing (Gan et al., 2013).

\section{Conclusion}

The starting point for the development of the housing system that China has embarked on was a redistributive system in the welfare period (1949-1978). In contrast to its egalitarian ambitions, a redistributive system tends to favor "redistributors" (socialist elites) rather than direct "producers" such as peasants and ordinary workers (Szelenyi, 1978). Instead of the capability to pay, a redistributive mechanism determined which urban households would have access to housing. Redistributive variables such as political loyalty (CPC membership) and organizational affiliation (work unit status) were strongly associated with households' housing outcomes (Zhang, 1997; Logan et al., 1999; Zhao \& Bourassa, 2003; Sato, 2006).

According to Nee's market transition theory, the transformation from a redistributive to a market economy would mitigate systemic inequality (Nee, 1989). However, the gradualism and dual-track approach that marked the transition would lead to economic distortion and market segregation (Young, 2000). In the dual period (1979-1998), housing was provided by both work units and the market, each imposing its own cost structure and property rights. Reformed housing - that is, subsidized home ownership in dwellings provided by work units or the State-was only accessible to those who were privileged in the tradi- 
tional socialist system. Less-privileged citizens and migrants had to purchase commodity housing at the market price. Thus, the housing market was segregated along the lines of social status (Pan, 2003).

Even when China moved into the post-reform era and the main housing provider was the market, distortions from the past were still manifest in the segregation and differentiation of society (Chen, 2015). The gap between privileged and non-privileged urban households widened with the inflation of property prices (1999-2011). Privileged households have seen their wealth increase substantially, whereas non-privileged households face serious accessibility and affordability problems. With market regulation policies that prohibit purchase by non-local buyers or charge them higher prices, not having a local hukou puts immigrants in an inferior market position.

After 2011, the central government pursued the goal of social inclusion under its new normal economy in view of declining export revenue and the urgency of boosting the domestic market. Housing provision moved into a comprehensive period (2011-2015) in which public rental housing would develop alongside commodity housing. The rental market would be further developed by allowing the Housing Provident Fund to offer a rent subsidy to low-income households. The hukou reform and the real estate registration system together provide the technical grounds for a nationwide taxation on extra housing properties. On the other hand, these policies would make rural residents more active players by bestowing on them the opportunity to turn their property in rural areas into liquid assets.

When the inferior market position attached to newcomers' hukou status has been repaired, and when rural residents can treat their properties in the countryside as financial resources, as their urban peers do with their properties in cities, the urban housing market would become more inclusive. By constraining the opportunities for housing speculation by local elites who do not necessarily have a higher income but do possess more political and social capital, more stock would become available to households who really need it for habitation. Housing policy in China still gives priority to housing consumption and economic growth. Within that frame, the rising consumption of housing by immigrants, rather than solely by local residents and speculators, could make the housing market in urban China more inclusive.

A more inclusive market in this period does not mean that immigrants are completely integrated in the housing subsidy schemes and other local welfare arrangements at no cost to themselves. Nor does it mean that everybody in this market could afford to buy a home or would be covered by housing support schemes. It does, however, mean that immigrants can compete with locals on more equal footing. They might be able to achieve a similar living standard, provided they pay a similar, or at least not too much higher, price as their local peers.

Of course, an inclusive housing market is not necessarily an equal one. As- 
suming that China has established a "fair" housing market in which every consumer has the same access to housing according to their ability to pay and regardless of their institutional status. This does not mean that the outcomes of urban housing market in China will become equal. As private ownership and family wealth become increasingly common, real estate will constitute a new source of inequality in post-socialist China. Not only will direct intergenerational transfer of wealth, as discussed in the previous section, affect the young cohort's chances of accessing better housing, but higher consumption in the areas of health and education will affect the next generation's life chances in general (Wang, 2013), as it does in many western market economies. Those forms of consumption are strongly embedded in economic activity and are harder to modify by state policy. Whether the emerging tools of governance, notably unified residential registration and real estate registration, can effectively deal with such a challenge remains uncertain.

\section{References}

Barth, J. R., Lea, M., \& Li, T. (2012). China's Housing Market: Is a Bubble about to Burst? Santa Monica: Milken Institute.

http://assets1b.milkeninstitute.org/assets/Publication/ResearchReport/PDF/China-Hou singMarket.pdf

https://doi.org/10.2139/ssrn.2191087

Bian, Y. (2013). Chinese Social Stratification and Social Mobility. In H. Zhang, Z. Xue, S. Jiang, \& G. L. Lugar (Eds.), A Scholarly Review of Chinese Studies in North America. Ann Arbor: Association for Asian Studies.

Bian, Y. J., \& Liu, L. Y. (2005). Occupation, Home Ownership, and Housing Quality: Evidence from China's Fifth Census. Sociology Studies, No. 3, 82-98 + 243.

Chan, K. W., \& Zhang, L. (1999). The Hukou System and Rural-Urban Migration in China: Processes and Changes. The China Quarterly, No. 160, 818-855. https://doi.org/10.1017/S0305741000001351

Chen, G. (2011). Privatization, Marketization, and Deprivation: Interpreting the Homeownership Paradox in Postreform Urban China. Environment and Planning A, 43, 1135-1153. https://doi.org/10.1068/a43444

Chen, G. (2012). Structural Evaluation of Institutional Bias in China's Urban Housing: The Case of Guangzhou. Environment and Planning A, 44, 2867-2882. https://doi.org/10.1068/a45123

Chen, G. (2015). The Heterogeneity of Housing-Tenure Choice in Urban China: A Case Study Based in Guangzhou. Urban Studies, 53, 957-977. https://doi.org/10.1177/0042098015571822

Cheng, T., \& Selden, M. (1994). The Origins and Social Consequences of China's Hukou System. The China Quarterly, No. 139, 644-668. https://doi.org/10.1017/S0305741000043083

China.cn (2011). Standing Committee of People's Congress' Inquiring on Housing Security Condition. http://finance.sina.com.cn/g/20111027/095210702419.shtml

Cui, C., Geertman, S., \& Hooimeijer, P. (2016). Access to Homeownership in Urban China: A Comparison between Skilled Migrants and Skilled Locals in Nanjing. Cities, No. 50, 188-196. 
Deng, L., Shen, Q., \& Wang, L. (2011). The Emerging Housing Policy Framework in China. Journal of Planning Literature, 26, 168-183. https://doi.org/10.1177/0885412210390220

Deng, W. J., Hoekstra, J. S. C. M., \& Elsinga, G. M. (2016). The Changing Determinants of Homeownership amongst Young People in Urban China. International Journal of Housing Policy. https://doi.org/10.1080/14616718.2015.1135857

Fan, G. (1994). Incremental Changes and Dual-Track Transition: Understanding the Case of China. Economic Policy, 19, 99-122.

Fang, C. C. (2014). Institutional Segmentation and Housing Inequality in Urban China. Society, 34, 92-117.

Francis, C. B. (1996). Reproduction of Danwei Institutional Features in the Context of China's Market Economy: The Case of Haidian District's High-Tech Sector. China Quarterly, No. 147, 839-859. https://doi.org/10.1017/S0305741000051821

Gan, L., Yin, Z. C., Jia, N. et al. (2013). Analysis on the Asset Condition and Housing Needs of Chinese Families. Financial Research, No. 4, 1-14.

General Office of State Council (2013). Notice of the General Office of the State Council on Further Improving Regulation of the Real Estate Market. http://www.gov.cn/zwgk/2013-03/01/content_2342885.htm

He, X. B., Xia, F. et al. (2012). The Institutional Transfer and the Divergence of Urban Households' Wealth Distribution: Perspective of Asset Transformation. Economy Research, No. 2, 28-40 + 119 .

Ho, M., \& Kwong, T. M. (2002). Housing Reform and Home Ownership Behaviour in China: A Case Study in Guangzhou. Housing Studies, 17, 229-244. https://doi.org/10.1080/02673030220123207

Huang, X. (2015). Residential Mobility after Hukou Reform: Housing Strategies of Rural-Urban Migrants in China. PhD, Utrecht: Utrecht University.

Huang, X., Dijst, M., van Weesep, J., \& Zou, N. (2013). Residential Mobility in China: Home Ownership among Rural-Urban Migrants after Reform of Hukou Registration System. Journal of Housing and the Built Environment, 29, 615-636. https://doi.org/10.1007/s10901-013-9370-5

Huang, Y. Q. (2004). The Road to Homeownership: A Longitudinal Analysis of Tenure Transition in Urban China (1949-94). International Journal of Urban and Regional Research, 28, 774-795. https://doi.org/10.1111/j.0309-1317.2004.00551.x

Huang, Y. Q., \& Clark, W. (2002). Housing Tenure Choice in Transitional Urban China: A Multilevel Analysis. Housing Studies, 39, 7-32. https://doi.org/10.1080/00420980220099041

Huang, Y., \& Jiang, L. (2009). Housing Inequality in Transitional Beijing. International Journal of Urban and Regional Research, 33, 936-956. https://doi.org/10.1111/j.1468-2427.2009.00890.x

Huang, Y., \& Li, S. (Ed.). (2014). Housing Inequality in Chinese Cities. Oxon, New York: Routledge.

Jiang, L. (2006). Living Conditions of the Floating Population in Urban China. Housing Studies, 21, 719-744. https://doi.org/10.1080/02673030600807431

Lau, L. J., Qian, Y. Y., \& Roland, G. (2000). Reform without Losers: An Interpretation of China's Dual-Track Approach to Transition. Journal of Political Economy, 108, 120-143. https://doi.org/10.1086/262113

Li, B. (2009). Differentiation of Housing Policy: An Assessment to Housing Reform. Bei- 
jing: Social Science Press.

Li, S. M. (2000). Housing Consumption in Urban China: A Comparative Study of Beijing and Guangzhou. Environment and Planning A, 32, 1115-1134.

https://doi.org/10.1068/a32145

Li, S. M., \& Li, L. M. (2006). Life Course and Housing Tenure Change in Urban China: A Study of Guangzhou. Housing Studies, 21, 653-670. https://doi.org/10.1080/02673030600807159

Liu, Z., Wang, Y., \& Tao, R. (2013). Social Capital and Migrant Housing in Urban China. Housing Studies. https://doi.org/10.1080/02673037.2013.818620

Logan, J. R., Bian, Y. et al. (1999). Housing Inequality in Urban China in the 1990s. International Journal of Urban and Regional Research, 23, 7-25. https://doi.org/10.1111/1468-2427.00176

Logan, J. R., Fang, Y. P., \& Zhang, Z. X. (2009). Access to Housing in Urban China. International Journal of Urban and Regional Research, 33, 914-935. https://doi.org/10.1111/j.1468-2427.2009.00848.x

Logan, J. R., Fang, Y. P., \& Zhang, Z. X. (2010). The Winners in China's Urban Housing. Housing Studies, 25, 101-117. https://doi.org/10.1080/02673030903240660

Luo, C. L. (2013). Inequality of the Housing Reform, Income Divergence and Urban Housing. Economy and Management, No. 5, 5-10. http://www.iprcc.org.cn/Home/Index/down1/id/721.html

Mao, X. (2014). Housing Purchase: Stratification and Mobility under Changing Institutions. Society, 34, 118-139.

MHURD (2016). http://www.mohurd.gov.cn/dfxx/201602/t20160224_226736.html http://www.mohurd.gov.cn/dfxx/201601/t20160129_226496.htm

MHURD (Ministry of Housing and Urban and Rural Development) (2015). Approval Draft of Regulation of Housing Provident Fund. http://news.xinhuanet.com/fortune/2015-11/20/c_128450895.htm

MHURD et al. (2006). Ministry of Housing and Urban and Rural Development. On the Adjustment of the Housing Supply Structure and the Stabilization of the Housing Price. http://finance.sina.com.cn/chanjing/b/20060529/18262606651.shtml

National Academy Administration (2014). The New Normal of Chinese Economy. Beijing: People's Publishing House.

Nee, V. (1989). A Theory of Market Transition: From Redistribution to Markets in State Socialism. American Sociological Review, 54, 663-681.

https://doi.org/10.2307/2117747

NSB (National Statistic Bureau), Various Years. China Statistic Yearbook. http://www.stats.gov.cn/tjsj/ndsj/

NSB, National Statistical Bureau (2013). Chinese Statistical Yearbook. http://www.stats.gov.cn/tjsj/ndsj/2013/indexeh.htm

Pan, Z. F. (2003). Housing Quality Differentials in Urban China 1988-1995: Evidence from Two National Surveys. International Journal of Social Economics, 30, 1070-1083. https://doi.org/10.1108/03068290310492869

People.cn (2015). Household Registration Reform in Progress: 24 Provinces Issued Standards and Timeline.

http://politics.people.com.cn/n/2015/1001/c1001-27654197.html

Perry, E. J. (1997). From Native Place to Workplace: Labor Origins and Outcomes of China's Danwei System. In X. Lu, \& E. J. Perry (Eds.), Danwei: The Changing Chinese 
Workplace in Historical and Comparative Perspective (pp. 42-59). New York, NY: M.E. Sharpe, Inc.

Qiu, J. L. (2000). Interpreting the Dengist Rhetoric of Building Socialism with Chinese Characteristics. In D. R. Heisey (Ed.), Chinese Perspectives in Rhetoric and Communication (pp. 249-264). Stamford: Ablex Publishing Corporation.

Sato, H. (2006). Housing Inequality and Housing Poverty in Urban China in the Late 1990s. China Economic Review, 17, 37-50.

State Council (1978). Suggestion of Strengthening the Urban Construction. http://www.chinabaike.com/law/zy/bw/0973/1417920.html

State Council (1984). The State Council on the Problem of Farmers' Settlement in Towns. http://www.rmlt.com.cn/2014/0731/300534.shtml

State Council (1994). The State Council on Deepening the Reform of Urban Housing Institution. http://www.gov.cn/zhuanti/2015-06/13/content_2878960.htm

State Council (1998). The State Council on Circulating the Suggestions of Ministry of Public Security on Solving Several Serious Problems in Hukou Management. http://www.chinabaike.com/law/zy/bw/gw/gab/1342619.html

State Council (1998). The State Council on Further Deepening the Reform of Urban Housing Institution to Speed up the Construction of Housing. http://www.ggj.gov.cn/vfggw/qtfg/200806/t20080610_262964.htm

State Council (2003). The State Council on Promoting the Sustained and Healthy Development of the Real Estate Market.

http://www.lawinfochina.com/display.aspx?lib=law\&id=3078\&CGid

State Council (2011). Circular of the General Office of the State Council on Continuing to Regulate the Real Estate Market. http://www.gov.cn/zwgk/2011-01/27/content_1793578.htm

State Council (2014). Provisional Regulations on Real Estate Registration. http://www.gov.cn/zhengce/content/2014-12/22/content_9325.htm

State Council (2014). The State Council on Further Facilitating the Reform of Household Registration. http://www.gov.cn/zhengce/content/2014-07/30/content_8944.htm

State Council. (2012). National Plan of the Basic Public Service System during the 12th Five-Year Plan.

http://www.china.com.cn/policy/txt/2012-07/20/content_25965719.htm

Szelenyi, I. (1978). Social Inequalities in State Socialist Redistributive Economies. International Journal of Comparative Sociology, 19, 63-87. https://doi.org/10.1177/002071527801900105

Wang, F. L. (2004). Reformed Migration Control and New Targeted People: China's Hukou System in the 2000s. The China Quarterly, No. 177, 115-132. https://doi.org/10.1017/S0305741004000074

Wang, X. H., \& Li, G. H. (2011). Research on the Legislation of Chinese Public Rental Housing: Case of Beijing and Other 7 Cities. Journal of Gansu Administrative College, No. 5, 116-123.

Wang, Y. P. (1995). Public Sector Housing in Urban China 1949-1988: The Case of Xi'an. Housing Studies, 10, 57-82. https://doi.org/10.1080/02673039508720809

Wang, Y. P., \& Murie, A. (2000). Social and Spatial Implications of Housing Reform in China. International Journal of Urban and Regional Research, 24, 397-414. https://doi.org/10.1111/1468-2427.00254 
Wang. T. F. (2013). From Income Difference to Wealth Gap: New Trends in Social Inequality. Brookings-Tsinghua Center for Public Policy.

https://www.brookings.edu/wp-content/uploads/2016/06/income-inequality-wealth-ga p-china-social-trend-wang.pdf

Womack, B. (1991). An Exchange of Views about Basic Chinese Social Organization, Review Essay: Transfigured Community: Neo-Traditionalism and Work Unit Socialism in China. The China Quarterly, No. 126, 313-332.

https://doi.org/10.1017/S0305741000005221

World Bank (2016). http://data.worldbank.org/country/china

Wu, F. (2001). China's Recent Urban Development in the Process of Land and Housing Marketisation and Economic Globalisation. Habitat International, 25, 273-289. https://doi.org/10.1016/S0197-3975(00)00034-5

Wu, W. P. (2002). Migrant Housing in Urban China: Choices and Constraints. Urban Affairs Review, 38, 90-119. https://doi.org/10.1177/107808702401097817

Wu, W. P. (2004). Sources of Migrant Housing Disadvantage in Urban China. Environment and Planning A, 36, 1285-1304. https://doi.org/10.1068/a36193

Wu, X. G., \& Treiman, D. J. (2004). The Household Registration System and Social Stratification in China: 1955-1996. Demography, 41, 363-384. https://doi.org/10.1353/dem.2004.0010

Yi, C., \& Huang, Y. (2014). Housing Consumption and Housing Inequality in Chinese Cities during the First Decade of the Twenty-First Century. Housing Studies, 29, 291-311. https://doi.org/10.1080/02673037.2014.851179

Young, A. (2000). The Razor's Edge: Distortions and Incremental Reform. The Quarterly Journal of Economics, 154, 1091-1135. https://doi.org/10.1162/003355300555024

Zhang, X. Q. (1997). Chinese Housing Policy 1949-1978, the Development of a Welfare System. Planning Perspectives, 12, 433-455. https://doi.org/10.1080/026654397364618

Zhang, X. Q. (2002). Governing Housing in China: State, Market and Work Units. Journal of Housing and the Built Environment, 17, 7-20. https://doi.org/10.1023/A:1014849905206

Zhao, Y. S., \& Bourassa, S. C. (2003). China's Urban Housing Reform: Recent Achievements and New Inequities. Housing Studies, 18, 721-744. https://doi.org/10.1080/02673030304254

Zhou, M., \& Logan, J. R. (1996). Market Transition and the Commodification of Housing in Urban China. International Journal of Urban and Regional Research, 20, 400-421. https://doi.org/10.1111/j.1468-2427.1996.tb00325.x 